(c) American Dairy Science Association, 2006.

\title{
Periparturient Climatic, Animal, and Management Factors Influencing the Incidence of Milk Fever in Grazing Systems
}

\author{
J. R. Roche ${ }^{\star 1}$ and D. P. Berry† \\ *Dexcel Ltd., Hamilton, New Zealand \\ †Teagasc, Moorepark Dairy Production Research Centre, Fermoy, Co. Cork, Ireland
}

\begin{abstract}
The objective of the present study was to quantify the climatic, animal, and management factors influencing incidence of milk fever (MF) in cows exposed to grazing systems. Data were extracted on 4,469 calvings of multiparous cows in a seasonal calving research herd between 1970 and 2000. Climatic data during the calving period also were extracted for these years. Poisson regression was used to investigate the effect of climate on frequency of MF within year; the offset variable was the number of cows at risk for MF at that time. Generalized estimating equations, with cow included as a repeated effect, were used to quantify the effect of parturition-associated cow and management factors on the logit of the probability of MF. Both univariate and multivariate analyses were performed. Explanatory variables investigated included time of calving relative to the herd-year calving period, parity, body weight, breed of cow, body condition score at calving, weight and gender of the calf, incidence of twin calves, calving inductions, and calving assistance. Odds of recurring MF within cow, as well as the timing of MF relative to day of calving, was quantified using generalized estimating equations with cow included as a repeated effect. Results show significant effects of evaporation, minimum grass temperature, difference between ambient maximum and minimum temperature, and rainfall on the odds of MF occurring, with a greater incidence at greater evaporation, larger diurnal variation in air temperature, greater rainfall, and lesser grass minimum temperature. Cow factors, such as age, excessive or poor body condition score, and requirement for calving assistance increased the odds of MF; a lesser odds ratio was observed in cows hormonally induced to calve and those that had twin births. Results indicate that herd managers may identify the day of greatest risk for MF and cows that are at greatest risk of MF based on climatic, cow, and management factors.
\end{abstract}

Key words: transition cow, pasture, milk fever, climate

Received October 20, 2005.

Accepted February 14, 2006

${ }^{1}$ Corresponding author: john.roche@dexcel.co.nz

\section{INTRODUCTION}

Transition between late pregnancy and early lactation is a significant risk period for metabolic disorders in the dairy cow. Risk for milk fever (MF) is greatest within this period and is especially great around parturition, when blood Ca drops to subnormal concentrations (Goff and Horst, 1997). Depending on the severity of this decline, hypocalcemia can be either subclinical (i.e., without obvious clinical signs, but characterized by reduced smooth muscle function; Houe et al., 2001) or clinical, when blood Ca becomes insufficient to support nerve and muscle function (Schultz, 1971; Goff and Horst, 1997). Reduced blood Ca often results in MF, which is also known as parturient paresis because of the accompanying recumbency. Total blood Ca concentrations $<2 \mathrm{mmol} / \mathrm{L}$ generally classify cows as having subclinical hypocalcemia (Houe et al., 2001), with concentrations $<1.4 \mathrm{mmol} / \mathrm{L}$, usually defining clinical hypocalcemia (Lindsay and Pethick, 1983).

Milk fever was first reported in Germany in 1793 (Schultz, 1971) and has since been a well-researched subject because of its economic importance. Schultz (1971) reported a mortality rate of 5\% in those clinically affected and observed that productive life of affected cows was reduced by approximately $3.5 \mathrm{yr}$. In a review of the syndrome, Cox (1981) reported that between 4 and $28 \%$ of cows with MF relapse and may become downer cows. Between 20 and $67 \%$ of those affected cows die subsequently or must be slaughtered.

Daniel et al. (1990) showed that cows with depleted blood $\mathrm{Ca}(<1.9 \mathrm{mmol} / \mathrm{L})$ near calving also had decreased blood Ca through 45 DIM, possibly having negative effects on milk production and reproduction. In addition, Block (1984) reported a 14 and $7 \%$ reduction in milk yield in cows that experienced clinical and subclinical parturient hypocalcemia, respectively. Belonje and Van der Walt (1971) reported poorer fertility (prolonged intercalving period) in cows that contracted MF.

Milk fever is reported to occur in 3 to $10 \%$ of dairy cows (Houe et al., 2001; Roche, 2003a), although this varies among farms, production systems, and seasons. Based on a review of the literature, Roche (2003a) concluded that MF incidence in pasture systems approxi- 
mated $2 \%$, although the incidence of clinical hypocalcemia (blood $\mathrm{Ca}<1.4 \mathrm{mmol} / \mathrm{L}$ ) was probably greater $(\sim 5 \%)$. Control strategies vary (see reviews by Horst et al., 1997; Roche, 2003a) and often depend on subjective judgment of management, intuition, attitudes to risk, and assumed economic costs and benefits (Houe et al., 2001). A sound knowledge of the factors affecting the onset of MF is imperative if a successful prevention strategy is to be implemented. Such information has led to altering nutritional strategies, such as increased $\mathrm{Mg}$ supplementation or reduced precalving dietary cation-anion differences (Roche, 2003a) aimed at minimizing incidence of MF. Although these nutritional practices have dramatically reduced the incidence of $\mathrm{MF}$, they have failed to eradicate it fully.

Many nonnutritional factors, such as age and breed (Horst et al., 1997), genetic strain (Roche, 2003b), and environmental stressors may contribute to MF. Research aimed to prevent MF, however, has primarily focused on dietary factors that influence the cows' ability to intestinally absorb dietary $\mathrm{Ca}$ and resorb bone $\mathrm{Ca}$, largely ignoring nonnutritional stressors that may play a role in the etiology of metabolic disorders. Circumstances that induce stress, such as parturition, social group change, or adverse climatic conditions have been associated with metabolic disorders (McCoy, 1999). An understanding of how they affect incidence of hypocalcemia allows the establishment of preventive measures during the period of greatest challenge.

Although barometric pressure has been negatively associated with the incidence of MF (Simensen, 1974), very little is known about the effects of climate on the incidence of this disorder. Most reports examining the effect of climate on the incidence of metabolic disorders were done using sheep (Bruere, 1975; Berman et al., 1980), and the few bovine studies were undertaken more than $30 \mathrm{yr}$ ago, but did not involve grazing cows (Hibbs and Pounden, 1951; Simensen, 1974). The objective of the present study was to determine and quantify the climatic, management, and cow factors that have greatest influence on the incidence of $\mathrm{MF}$ in grazing dairy cows using data collected during a $30-y r$ period.

\section{MATERIALS AND METHODS}

Data were extracted from the Dexcel research database including 5,923 calvings of 1,623 cows at No. 2 dairy research farm between 1970 and 2000. The No. 2 dairy farm was used for systems-based research, and the period in question incorporated 115 research treatments undertaken during multiple lactations (220 different herd $\times$ year farmlets) comparing the profitability of Holstein-Friesian and Jersey cows in grazing systems, different pasture species and cultivars, different grazing rotation durations, systems that optimized use of nitrogen fertilizer and supplementary feeds, and research to determine the most profitable stocking rate for grazing dairy systems. Mean herd size across the years was 188 cows.

Grazing regimens varied very little between treatments. In general, herbage was grazed when between 2 and 3 leaves had regrown on the majority of perennial ryegrass tillers (approximately $2,500 \mathrm{~kg}$ of DM/ha in spring, 4,000 kg of DM/ha in summer, and $3,000 \mathrm{~kg}$ of $\mathrm{DM} / \mathrm{ha}$ in fall and winter; all measurements were to ground level). Postgrazing residuals approximated 40 $\mathrm{mm}$ during winter and spring, and $60 \mathrm{~mm}$ during summer and fall. Detailed accounts of management decision rules are provided by Macdonald and Penno (1998).

Throughout the period investigated, the precalving diet would have consisted largely of fresh pasture (predominantly perennial ryegrass; Lolium perenne L.) and pasture silage (approximately 50:50 mix), and cows were fed to maintain BCS. Soils were fertile silt loams (Aquic Dystandepts, Haplic Andaquepts, Umbric Vitrandepts) and peaty silt loams (Humic Haptorthod). The farm received annual "maintenance" dressings of $54 \mathrm{~kg}$ of $\mathrm{P} / \mathrm{ha}$ and $55 \mathrm{~kg}$ of $\mathrm{S} / \mathrm{ha}$ as Superphosphate $\left[\mathrm{Ca}\left(\mathrm{H}_{2} \mathrm{PO}_{4}\right)_{2} \cdot \mathrm{CaSO}_{4}\right]$ in November, and $50 \mathrm{~kg}$ of $\mathrm{K} / \mathrm{ha}$ as muriate of potash $(\mathrm{KCl})$ in March. Across the years being studied, nitrogen application rate varied from 172 to $286 \mathrm{~kg}$ of N/ha.

The system of milk production was seasonal, with approximately $50 \%$ of cows calving in $2 \mathrm{wk}, 40 \%$ calving during the next $4 \mathrm{wk}$, and the remaining cows calving during the seventh and eighth weeks. Any cow whose planned calving date was later than the eighth week was hormonally induced to calve during the seventh and eighth weeks using a 2-step combination of dexamethasone (Opticortenol S, Novartis Animal Health, Switzerland; Voren, Boehringer-Ingelheim, UK) and prostaglandin $\mathrm{F}_{2 \alpha}$ (Estrumate, Schering-Plough Coopers, Wellington, NZ), provided SCC at dry off were $<200,000$, BCS of cows were $\geq 3.0$, and blood $\mathrm{Mg}$ and $\gamma$-glutamyl transferase measured the week preceding planned induction did not indicate health concerns.

Breed of cows on the research farm changed with time. In 1970, 100\% of cows were Jersey. By 1980, 95\% were crossbred Jersey-Friesian, and in 1990 and 2000, 35 and $0 \%$ of cows, respectively, were Jersey, with the remaining cows being Holstein-Friesian.

\section{Data}

Climatic data were collected at a weather station $<1.5$ $\mathrm{km}$ from the research farm and were available from July 1970 to the end of September 2000. Seasonal nature of calving under pasture-based systems meant that 
$>90 \%$ of cows in each year calved before September 1 . Therefore, climatic data were only extracted for July, August, and September.

Data included relative humidity (\%), 24-h minimum and maximum air temperature $\left({ }^{\circ} \mathrm{C}\right), 24$-h minimum herbage temperature $\left({ }^{\circ} \mathrm{C}\right)$, soil temperature $\left({ }^{\circ} \mathrm{C}\right)$ at 10 $\mathrm{cm}$, wind run ( $\mathrm{km}$ over $24 \mathrm{~h})$, wind force $(\mathrm{m} / \mathrm{s}), 24-\mathrm{h}$ rainfall $(\mathrm{mm}), 24-\mathrm{h}$ evaporation $(\mathrm{mm})$, and number of sunlight hours. An additional climate variable was calculated as the difference between maximum and minimum temperature. Average of each climate variable for the day under investigation and either the previous day or the previous $4 \mathrm{~d}$ was calculated.

Occurrence of MF was based on the herd manager's assessment of a periparturient downer cow. Records were available on most of the animals for year of birth, calving date, parity, breed, BW and BCS at calving, artificial induction of calving, degree of calving assistance (scale of 1 to $3,1=$ no assistance and $3=$ veterinary assistance needed), date of MF, if contracted, culling date and reason, and birth weight and gender of calf. The BCS data were only available from 1978 onwards. Body condition score was assessed on a 10-point scale, where $1=$ emaciated and $10=$ obese (Macdonald and Roche, 2004). These scores were then converted to the 5 -point scale using the regression equation generated by Roche et al. $(2004 ; 5$-point scale $=1.5+0.3210$-point scale). Because no health records were available for cows in 1975, incidence of MF was not known, and these data were removed from all analyses.

Date of calving for each cow within herd year was extracted, facilitating the division of the annual calving period into quintiles. Each cow-parity was subsequently allocated into a quintile depending on her date of calving relative to the respective herd calving period in each year. Milk fever was observed in 16 primiparous cows. Primiparous cows rarely succumb to MF and so these records were considered misdiagnoses (possibly birth depression, nerve paralysis, or physical muscle trauma) and excluded from the analysis. Parity of cow was subsequently recoded as $2,3,4$, or $5+$. In total, 4,330 cows were available for inclusion in the analysis of evaluating the probability of MF at the cow level.

\section{Analyses}

Herd Level. Preliminary analyses of the data revealed that $99 \%$ of cows that contracted MF did so within a 3-d period around the day of calving. Hence, this period was assumed to be the associated "risk period". Based on individual calving dates, and the defined risk period, the number of cows at risk for contracting MF were calculated for each calendar date. Subsequently, the number of cows at risk and the prevalence of MF for each calendar day were merged with the previously calculated 2- and 5-d average climate. In total, 2,186 dates, when at least 1 cow was at risk for contracting MF, were available for inclusion in the analysis at a herd level.

All climatic variables with the exception of rainfall were converted into class variables based on quintiles across the whole data set to elucidate any possible nonlinear relationships between climate and incidence of MF. Twenty-five percent of the records had an average rainfall of 0 . Hence, average rainfall was divided into 5 classes: 0 rainfall, and quartiles of the remaining rainfall records. Range of climatic variables averaged over $2 \mathrm{~d}$ are summarized in Table 1 for the different categories.

Analyses were subsequently carried out to quantify the effect, if any, of climate on the frequency of MF. Daily frequency of MF was the dependent variable (varied from 0 to 4 cases/d). Mean and variance of the daily frequency of MF were 0.12 and 0.15 , respectively. Independent variables, coded as classified variables, were investigated within the model assuming a Poisson distribution of the frequency of MF. The middle category was restricted to be the reference class for all climatic variables with the exception of rainfall in which the category of zero rainfall was defined as the reference class. Classification variables were used to determine the possible presence of systematic nonlinear relationships between climate and daily frequency of MF as well as overcoming the nonnormality of some climatic variables. The natural logarithm of the daily number of cows at risk was used as an offset variable in the model of analysis.

Independent variables were selected based on a stepwise forward-backward selection algorithm. Significance level for entry and exit of variables from the model were $P<0.25$ and $P<0.10$, respectively. Rate ratios were derived as the exponent of the model solutions.

Cow Level. Possible independent variables for inclusion in the model of analysis were created. These effects included 1) year of calving, 2) parity, 3) breed, 4) time of calving relative to the annual calving season (as quintiles), 5) BW immediately postcalving (as deciles), 6) BCS at calving, 7) sex of calf, 8) weight of calf (as deciles), 9) whether a cow was artificially induced to calve or not, 10) whether assistance at calving was required or not, and 11) single vs. twin births. Although it is acknowledged that other cow factors (Goff and Horst, 1997), such as milk production, affect the incidence of MF, because of the age of the data being analyzed ( $35 \mathrm{yr}$ ) additional animal data were not available.

Breed fraction was only available for $80 \%$ of the data and was strongly associated with year of calving (i.e., Jersey cows were the predominant breed in the 1970s, 
Table 1. Ranges in climatic variables averaged (unless otherwise stated) over the previous $48 \mathrm{~h}$ for each of the 5 categories

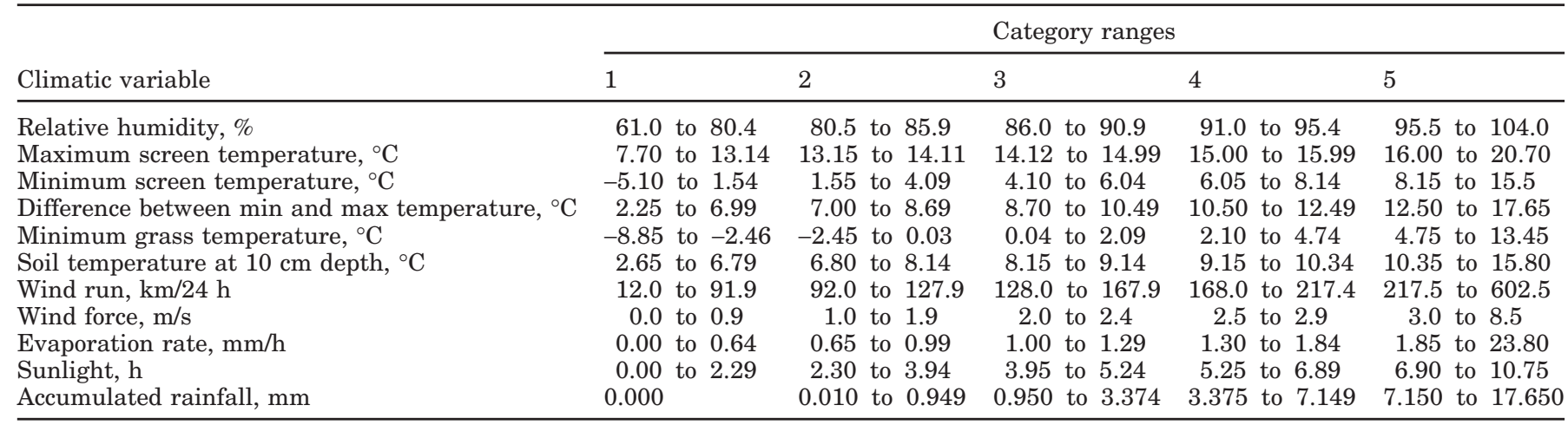

whereas Holstein-Friesian cows were the only breed on the farm in the mid to late 1990s). Immediate postcalving BW was recoded based on deciles as was weight of the resultant calf. The thresholds used to separate BW into deciles were $335,364,385,402,420,439,457,482$, $518,420,442,466$, and $504 \mathrm{~kg}$, whereas the thresholds for calf birth weight were $30.8,33,35,36.5,38,40$, and $42.5 \mathrm{~kg}$. Because of limited numbers of observations for extremely high or low BCS at calving, records with a $\mathrm{BCS} \leq 2.5$ were coded as 2.5 , whereas BCS records $\geq 3.5$ were coded as 3.5.

Three separate types of analyses were undertaken using cow as the experimental unit.

Model I: Probability of Milk Fever. Repeated records per cow were available across years. Hence, generalized estimating equations (GEE) were used to model logit of the probability that a cow exhibited MF as:

$$
\operatorname{Logit}\{\mathrm{P}(\mathrm{D}=1 \mid \mathrm{X})\}=\mathrm{Xa}+\mathrm{Zb}+\varepsilon
$$

where $a, b$, and $\varepsilon$ are the vectors of fixed effects, cow effects, and random residuals and $\mathrm{X}$ and $\mathrm{Z}$ are the respective design matrices.

An exchangeable correlation structure was assumed among records within cow. The empirical standard errors of the solutions for the fixed effects are reported herein. Univariate analyses on each of the explanatory variables were initially undertaken in PROC GENMOD (SAS Institute, 2005), with cow included as a repeated effect. For the univariate analyses only, a data set was created in which records with missing values for any of the possible explanatory variables were removed, the exception being breed code because removing cow records that had a missing value for breed resulted in a smaller data set.

Subsequently, a multivariate model was created using a forward-backward stepwise algorithm where $P<$ 0.25 and $P<0.10$ were used as the threshold significance levels for entry and exit of variables from the model, respectively. Level of significance was based on the GEE score statistic. Biologically plausible interactions also were tested for significance while simultaneously ensuring that no problems of quasi-complete separation of the data existed. A separate multivariate analysis was undertaken with or without breed considered for inclusion in the model. Interactions with breed also were tested for significance in the model.

The probability of an animal getting MF was estimated using the results from the multivariate analysis as

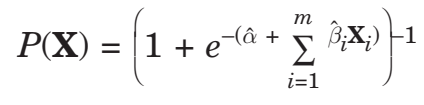

where $\alpha$ is the predicted intercept of the multivariate model, $\beta$ is the predicted regression coefficient for independent variable(s) $i$, and $\mathrm{X}_{i}$ are the associated design matrix for variable(s) $i$. Odds ratios were calculated as the exponent of the model solutions.

Model II: Probability of Recurrence of Milk Fever. A new variable was created in the data to represent the existence or lack of MF in the previous lactation. For this analysis, the earliest record of each cow in the data set was removed. Following this edit, 4,045 records were retained. The dependent variable in the analysis was the logit of the probability of MF in the current lactation. The analysis was undertaken using PROC GENMOD (SAS Institute, 2005) assuming a logit-link function and binomial distribution. Cow was included as a repeated effect in the model with an exchangeable correlation structure assumed between records within cow. The model used was that previously derived in the multivariate analysis with the added explanatory binary variable of incidence of MF in the immediately previous lactation. The odds ratio associated with incidence of MF in the previous lactation was calculated as the exponent of the associated model solution for that variable. 
Model III: Probability of Timing of Milk Fever Relative to Calving. The odds of a cow contracting MF $3 \mathrm{~d}$ precalving through $3 \mathrm{~d}$ postcalving was investigated using GEE in PROC GENMOD (SAS Institute, 2005) utilizing a logit function and assuming a binomial distribution. Cow was included as a repeated effect with an exchangeable correlation structure assumed between records within cow. All cows were included in the data set with 7 records each (i.e., $-3,-2,-1,0,1,2$, and $3 \mathrm{~d}$ relative to calving). The day corresponding to when MF was observed was coded as 1 or otherwise 0 . Day relative to actual calving was included as an explanatory variable.

An additional analysis was undertaken to quantify possible contributing factors to when a cow exhibited MF relative to actual calving date. In this analysis, 7 records per cow (i.e., $3 \mathrm{~d}$ pre- to $3 \mathrm{~d}$ postcalving) were included only for cow-years that exhibited MF. The 7 records were condensed into a categorical variable with 3 levels: MF precalving, at calving (i.e., d 0), or postcalving. Explanatory variables considered for inclusion in the model were those previously described such as year, parity, time of calving relative to herd-mates, BCS, BW, birth weight and gender of calf, degree of calving assistance, and whether the cow was induced to calve. To model these possible relationships, a polytomous logistic regression was adopted using PROC CATMOD (SAS Institute, 2005). The reference category was assumed to be day of calving (i.e., d 0). Because of the small frequency of $\mathrm{MF}$ precalving, however, convergence problems arose because of quasi-complete separation of the data across most variables. Hence, parity was excluded from the analysis and BCS was recoded as $<3$, 3 , or $>3$ BCS units. Variables where quasi-complete separation of the data was not a problem were calf gender, calving assistance, and the recoded BCS variables. Hence, only these variables were analyzed.

\section{RESULTS AND DISCUSSION}

\section{Year Effects}

Figure 1 illustrates the incidence of MF per year as a proportion of the number of cows in the herd. Milk fever incidence in the decade between 1970 and 1979 averaged $13.1 \%$ but decreased with time to $4.5 \%$ in the $1980 \mathrm{~s}$, and $3.2 \%$ in the $1990 \mathrm{~s}$. The reason for this decline is probably related to the gradual change of breed from Jersey to Jersey-Holstein-Friesian crosses during the 1970s, and the continued change to Holstein-Friesian during the 1980s and 1990s. Channel Island breeds are known to be more susceptible to MF than HolsteinFriesian cows (Schultz, 1971; Lindsay and Pethick, 1983; Horst et al., 1997), probably because of reduced concentrations of intestinal receptors for $1,25(\mathrm{OH})_{2^{-}}$ vitamin $\mathrm{D}_{3}$ (Goff et al., 1995). Lean et al. (2006) reported that Jersey cows were at 2.25 times greater risk of MF than Holstein-Friesian cows. This effect of breed was also evident, but more pronounced, in the current study, with an almost 4 -fold greater odds [95\% confidence interval (CI): 2.6 to 5.7] of MF in Jersey cows relative to Holstein-Friesian in the univariate analysis and a nearly 5 -fold greater odds of MF in the multivariate analysis. The effect of breed is consistent with the literature and is probably the main reason for the observed decline in MF incidence with time in the current study.

Another possible reason for the reduction in $\mathrm{MF}$ with time was the introduction of precalving $\mathrm{Mg}$ supplementation (approximately $12 \mathrm{~g} / \mathrm{cow}$ per day) beginning in the late 1970s ( 1978) at the current farm. Magnesium is critical in the maintenance of eucalcemia (Sansom and Manston, 1983), playing a pivotal role in the parathyroid hormone response to hypocalcemia. Consistent with the previous study and our observations, Lean et al. (2006) reported that prepartum dietary Mg concentrations had the largest dietary effect on decreasing the incidence of MF.

\section{Climatic Effects}

In addition to the numerous metabolic challenges experienced by the transition dairy cow, climatic conditions also have been identified as possible factors influencing the incidence of metabolic disorders and mastitis (Simensen, 1974). Unfavorable climatic conditions can disturb the physiological balance in animals (Simensen, 1974), increasing the incidence of metabolic disorders. Damgaard (1975) found a strong relationship between MF incidence and sun-spot activity, suggesting that the endocrine glands of cattle may be affected by variations in UV radiation. Climatic variables, averaged between the current and previous day, that significantly affected the frequency of MF in dairy cows in the current study, as well as the predicted solutions per category, are summarized in Table 2. Only average evaporation rate and the difference between maximum and minimum screen temperature significantly affected the frequency of MF occurrence when averages of the current and previous 4 $\mathrm{d}$ were included in the analysis. Therefore, only results from the average of $2 \mathrm{~d}$ before calving are reported.

Univariate Poisson regression analysis revealed that average rate of evaporation, difference between maximum and minimum screen temperature, minimum grass temperature, and rainfall averaged during the previous $48 \mathrm{~h}$ affected $(P<0.05)$ the frequency of MF. Incidence of MF increased linearly with increasing rate of evaporation, and was greatest in cold, wet weather, and with large differences between maximum and minimum temperature. The present results indicate that, 


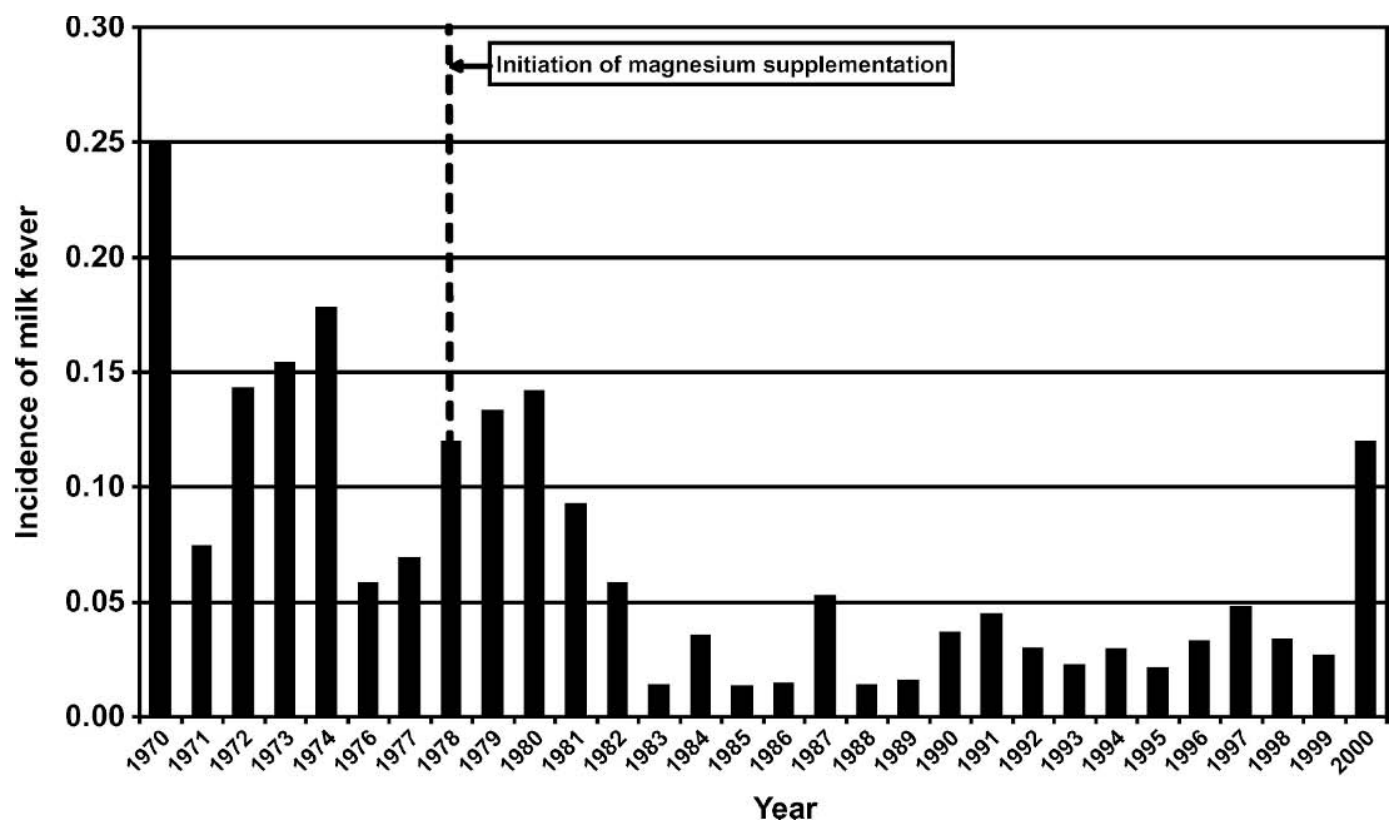

Figure 1. Proportion of cows contracting milk fever in pasture-based dairy production systems across year (excluding first-lactation cows).

on average, cows will get MF $82 \%$ more often if rainfall during the past $48 \mathrm{~h}$ is between $0.950 \mathrm{~mm}$ and 3.374 $\mathrm{mm}$ compared with no rain. Similarly, frequency of MF was $60 \%$ greater when minimum grass temperature was least $\left(-8.85\right.$ to $\left.-2.46^{\circ} \mathrm{C}\right)$ compared with a temperature around the median $\left(0.04\right.$ to $\left.2.09^{\circ} \mathrm{C}\right)$.

In agreement with the present results, Simensen (1974) reported an increased incidence of MF during periods of rainfall, particularly during winter, and Reid (1962) reported an increased incidence of metabolic disorders in sheep during inclement weather. Some of the effect of rainfall could be a result of reduced DMI because of altered grazing behavior. Reid (1962) also suggested this, but conceded that much of the effect could be a result of stress-induced adreno-cortical hyperactivity. It is not clear why evaporation rate would influence the incidence of MF. It may be little more than an indicator of ambient temperature change. Evapotranspiration rate has been positively associated with maximum air temperature and negatively associated with minimum air temperature during winter and spring (our unpublished data). Thus, evaporation rate in-

Table 2. Level of significance and rate ratios (95\% confidence intervals in parentheses) for the 4 climatic variables during the previous $48 \mathrm{~h}$ that significantly affected the frequency of milk fever based on the univariate analyses

\begin{tabular}{lllll}
\hline & \multicolumn{3}{c}{ Trait } \\
\cline { 2 - 5 } & Evaporation & $\begin{array}{l}\text { Difference in } \\
\text { temperature }\end{array}$ & $\begin{array}{l}\text { Minimum grass } \\
\text { temperature }\end{array}$ & Rainfall \\
\hline$P$-value & $<0.05$ & $<0.01$ & $<0.01$ & $<0.05$ \\
Category $^{1}$ & & & & \\
1 & $0.83^{\mathrm{a}}$ & $0.55^{\mathrm{a}}$ & $1.60^{\mathrm{ac}}$ & $1.00^{\mathrm{a}}$ \\
& $(0.51,1.33)$ & $(0.33,0.92)$ & $(0.98,2.62)$ & $1.28^{\mathrm{ab}}$ \\
& $0.86^{\mathrm{a}}$ & $1.14^{\mathrm{b}}$ & $1.55^{\mathrm{ac}}$ & $(0.75,2.17)$ \\
& $(0.54,1.38)$ & $(0.74,1.74)$ & $(0.97,2.46)$ & $1.82^{\mathrm{b}}$ \\
& $1.00^{\mathrm{ab}}$ & $1.00^{\mathrm{b}}$ & $1.00^{\mathrm{ab}}$ & $(1.13,2.94)$ \\
& & & & $1.73^{\mathrm{b}}$ \\
& $0.99^{\mathrm{a}}$ & $1.09^{\mathrm{b}}$ & $1.69^{\mathrm{c}}$ & $(1.06,2.84)$ \\
& $(0.60,1.62)$ & $(0.70,1.71)$ & $(1.06,2.70)$ & $1.57^{\mathrm{ab}}$ \\
& $1.56^{\mathrm{b}}$ & $0.96^{\mathrm{b}}$ & $0.84^{\mathrm{b}}$ & $(0.94,2.63)$ \\
\hline
\end{tabular}

${ }^{\mathrm{a}-\mathrm{c}}$ Rate ratios bearing different superscript letters within column $\operatorname{differ}(P<0.05)$.

${ }^{1}$ Categories were outlined in Table 1. 
creases with increasing maximum temperatures and decreasing minimum temperatures, consistent with the positive relationship between the diurnal variation in ambient temperature and MF in the current study.

Consistent with this thesis, no other climatic variable significantly affected the frequency of MF following adjustment for diurnal variation in air temperature in a multivariate analysis. Solutions from the multivariate analysis were similar to those from the univariate analyses summarized in Table 2 . The greatest diurnal variation in ambient temperatures occurs during periods of anticyclone weather patterns (high atmospheric pressure), in which very little cloud cover results in cold nights and warm sunny days (Philander, 1998). This explains the reported negative relationship between minimum grass temperature and the incidence of $\mathrm{MF}$ in the univariate analysis. Consistent with these results, Simensen (1974) reported a negative correlation between temperature and the incidence of MF in housed Norwegian dairy cows, and more recently, Schnier et al. (2002) found a negative relationship between ambient temperature (cold vs. warm housing) and MF incidence. Similarly, Mishra (1977) found a positive relationship between ambient temperature and serum Ca concentrations in Holstein-Friesian steers.

Some of the effect of temperature may be a result of an effect on DMI and resulting effects on plasma Ca. Although this may be partly true, others have found an effect of ambient temperature per se, on $\mathrm{Ca}$ and $\mathrm{Mg}$ homeostasis. Bruere (1975) reported significant biochemical changes associated with cold stress in sheep and Berman et al. (1980) showed a 67\% increase in urinary $\mathrm{Ca}$ excretion in lambs subjected to a 3-h cold shock $\left(-5^{\circ} \mathrm{C}\right)$. In addition, Shiga et al. (1985) reported increased hypomagnesemia when diurnal variation in ambient temperature was greatest. Such a decrease in blood $\mathrm{Mg}$ also would be expected to result in hypocalcemia (Sansom and Manston, 1983).

\section{Cow and Management Effects}

Model I: Probability of Milk Fever. Table 3 summarizes the significance of effects of animal and management factors on the probability of a cow exhibiting $\mathrm{MF}$, as well as the associated odds ratios for each level of the class variables presented (from both the univariate and multivariate analysis). Not included in the table is BW, time of calving relative to herd mates, and gender of calf, which did not affect the probability of MF in either analysis. Although year of calving was found to affect $(P<0.001)$ the incidence of MF, it was not included in Table 2 because of the lack of biological importance of solutions for each year. The solution for the intercept term in the multivariate analysis was
$-3.79(\mathrm{SE}=0.4)$. Results from the multivariate analysis reported in Table 2 are those without breed included in the model. When breed was included in the multivariate analysis $(P<0.01)$, the significance level of all terms remained similar to when breed was not included in the model. A Jersey had a 4.96 greater odds (95\% CI: 2.28 to 10.78) of getting MF compared with a HolsteinFriesian, whereas the Holstein-Friesian Jersey crossbred had a 2.44 times greater odds (95\% CI: 0.91 to 6.50) of getting MF. This is similar to results from the univariate analysis discussed earlier.

The univariate analysis identified significant effects of parity, BCS, calf birth weight, incidence of twinning, and incidence of calving induction. The odds of MF occurring were greater in older cows, and those that had a BCS $\geq 3.5$ or $\leq 2.5$ BCS. Cows induced to calve or those having twins had a lesser risk of getting MF. Of these factors, only parity, assistance at calving, and whether parturition was induced hormonally were significant in the multivariate analysis following adjustment for year of calving.

Increase in the incidence of MF with parity observed in the present study has been well established (Schultz, 1971; Horst et al., 1997), and is believed to be a result of a reduced ability to mobilize bone $\mathrm{Ca}$, a decline in intestinal transport of $\mathrm{Ca}$, and reduced ability to produce 1,25-( $\mathrm{OH})_{2}$-vitamin $\mathrm{D}_{3}$ in older cows (Horst et al., 1997). Probability of MF in a fifth or greater parity cow, of average BCS without calving induction, and with no required calving assistance was $13.3 \%$. The corresponding actual incidence observed across all fifth or later parity cows was $11.8 \%$.

The nonlinear effect of calving BCS is probably a result of attenuated postcalving DMI in cows with excessive BCS $(>3)$ and very poor BCS $(\leq 2.0)$ at calving (Stockdale, 2001) and increased milk production supported by catabolism of tissue reserves in cows of greater BCS at calving (Roche et al., 2005). Roche et al. (2005) reported an increase in milk protein production in cows of greater BCS at calving, signifying an increase in Ca secretion, because the majority of $\mathrm{Ca}$ in milk is contained in the casein micelle (Davies et al., 1983). A greater calving BCS would therefore increase the output of $\mathrm{Ca}$ and potentially reduce the $\mathrm{Ca}$ intake immediately postpartum, predisposing prospective cows to MF.

Although the doubling of odds of MF in cows requiring assistance would probably be expected, significantly reduced odds of developing MF in cows that were either hormonally induced to calve or who gave birth to twins was unexpected. It was not possible to determine from the current data whether cows required assistance because they were hypocalcemic (reduced smooth muscle function) or whether the stress of dystocia induced the 
Table 3. Significance, number of records (n), odds ratios, and lower (95\% LCI) and upper (95\% UCI) confidence intervals from univariate and multivariate analyses for cow and management variables that affected the probability of a cow exhibiting milk fever

\begin{tabular}{|c|c|c|c|c|c|c|c|c|c|c|}
\hline \multirow[b]{2}{*}{ Trait } & \multirow[b]{2}{*}{ Level } & \multirow[b]{2}{*}{$\mathrm{n}$} & \multicolumn{4}{|c|}{ Univariate analysis } & \multicolumn{4}{|c|}{ Multivariate analysis } \\
\hline & & & $\begin{array}{l}\text { Odds } \\
\text { ratio }\end{array}$ & $\begin{array}{l}95 \% \\
\text { LCI }\end{array}$ & $\begin{array}{l}95 \% \\
\text { UCI }\end{array}$ & $P$-value & $\begin{array}{l}\text { Odds } \\
\text { ratio }\end{array}$ & $\begin{array}{l}95 \% \\
\text { LCI }\end{array}$ & $\begin{array}{l}95 \% \\
\text { UCI }\end{array}$ & $P$-value \\
\hline \multirow[t]{4}{*}{ Parity } & 2 & 1,080 & 0.48 & 0.19 & 1.21 & $<0.001$ & 0.27 & 0.11 & 0.70 & $<0.001$ \\
\hline & 3 & 866 & 1.00 & & & & 1.00 & & & \\
\hline & 4 & 734 & 2.30 & 1.22 & 4.36 & & 3.18 & 1.64 & 6.15 & \\
\hline & 5 & 1,648 & 7.43 & 4.18 & 13.21 & & 12.42 & 6.67 & 23.14 & \\
\hline \multirow[t]{10}{*}{ Calf weight ${ }^{1}$} & 1 & 402 & 1.12 & 0.56 & 2.22 & $<0.05$ & & & & $\mathrm{NS}^{2}$ \\
\hline & 2 & 340 & 1.06 & 0.50 & 2.25 & & & & & \\
\hline & 3 & 400 & 0.78 & 0.38 & 1.62 & & & & & \\
\hline & 4 & 500 & 0.93 & 0.44 & 1.94 & & & & & \\
\hline & 5 & 273 & 1.00 & & & & & & & \\
\hline & 6 & 495 & 1.33 & 0.70 & 2.52 & & & & & \\
\hline & 7 & 525 & 1.93 & 1.01 & 3.70 & & & & & \\
\hline & 8 & 416 & 1.67 & 0.81 & 3.44 & & & & & \\
\hline & 9 & 390 & 1.16 & 0.57 & 2.34 & & & & & \\
\hline & 10 & 587 & 1.77 & 0.93 & 3.37 & & & & & \\
\hline \multirow[t]{5}{*}{ BCS } & $\leq 2.50$ & 159 & 1.13 & 0.32 & 4.05 & $<0.05$ & & & & NS \\
\hline & 2.75 & 614 & 0.56 & 0.34 & 0.92 & & & & & \\
\hline & 3.00 & 1,984 & 1.00 & & & & & & & \\
\hline & 3.25 & 483 & 0.96 & 0.63 & 1.45 & & & & & \\
\hline & $\geq 3.50$ & 239 & 1.31 & 0.56 & 3.08 & & & & & \\
\hline \multirow{2}{*}{ Assisted calving } & No & 4,143 & & & & NS & 1.00 & & & $<0.10$ \\
\hline & Yes & 185 & & & & & 2.01 & 1.07 & 3.79 & \\
\hline \multirow[t]{2}{*}{ Induced calving } & No & 3,972 & 1.00 & & & $<0.001$ & 1.00 & & & $<0.01$ \\
\hline & Yes & 356 & 0.42 & 0.21 & 0.83 & & 0.48 & 0.24 & 0.96 & \\
\hline \multirow[t]{2}{*}{ Twins } & No & 4,241 & 1.00 & & & $<0.01$ & & & NS & \\
\hline & Yes & 87 & 0.20 & 0.02 & 1.73 & & & & & \\
\hline
\end{tabular}

${ }^{1}$ Percentiles: 1 = heavy and $10=$ light.

${ }^{2}$ Not significant.

hypocalcemia. Anecdotally, hormonal induction would be expected to increase the incidence of periparturient metabolic disorders, such as mastitis, $\mathrm{MF}$, and retained fetal membranes. Few published reports are available, however, to support such an effect on MF. Perhaps induced cows are in a more favorable physiological status, relative to MF, because normal parturition is not expected for weeks. Data presented here from both the univariate and multivariate analyses indicate a halving of the odds of MF in induced cows. Nevertheless, use of this technology as a management strategy for preventing $\mathrm{MF}$ in at-risk cows (older, better conditioned cows) requires further investigation.

Model II: Probability of Recurring Milk Fever. Incidence of MF during a previous lactation, following adjustment for all traits included in the multivariate analysis (with the exception of year of calving) was positively correlated $(P<0.01)$ with $\mathrm{MF}$ incidence in the current lactation. Solutions from the multivariate analysis are similar to those reported in Table 3. The odds of MF in the current lactation was 2.2 (95\% CI: 1.35 to 3.63) times greater in cows that had MF in the previous lactation compared with those that did not. Hence, a fifth-parity cow of average BW at calving, without induction or assistance had a $28.4 \%$ greater probability of getting $\mathrm{MF}$ if she already had $\mathrm{MF}$ in the immediately previous lactation. This supports the premise that ability to adjust to a hypocalcemic challenge is genetically influenced, as indicated by recent heritability estimates of 0.09 to 0.13 for MF in Norwegian dairy cattle (Heringstad et al., 2005). Further, some breeds are known to be at greater risk of MF (Horst et al., 1997).

Model III: Timing of Milk Fever Relative to Calving. None of the variables investigated significantly affected when a cow would exhibit MF relative to her calving date. Within cows that exhibited MF, $88 \%$ succumbed on the day of calving or within $24 \mathrm{~h}$ after calving, with very small odds before calving. The odds ratio of MF occurring the day before calving was 0.44 compared with an odds of 1.00 on the day of calving. This probability highlights the well-documented periparturient depression in plasma Ca concentration (Goff and Horst, 1997), and agrees with reviews (Lindsay and Pethick, 1983) in which the majority (75\%) of MF cases occurred on the day of calving and the day after calving.

\section{CONCLUSIONS}

Climate influences the susceptibility of grazing cows to MF, with greater incidences when diurnal variation 
in temperature is greatest. Later parity (older), fat, or very thin cows, cows that exhibited MF previously, and cows requiring assistance at calving were at increased risk of MF. Hormonal induction and multiple births significantly reduced the risk of MF. This information can be used to better protect at-risk cows in grazing systems through increased vigilance by herd personnel and implementation of additional control strategies during at-risk periods for at-risk cows.

\section{ACKNOWLEDGMENTS}

The authors acknowledge the considerable assistance of J. Lee, K. Macdonald, and J. Lancaster. Our thanks also to David Beede and Phil Rogers for the inspiration to undertake this study.

\section{REFERENCES}

Belonje, P. C., and K. Van der Walt. 1971. Milk fever in a large Jersey herd. 1. The incidence of the condition. J. S. Afr. Vet. Med. Assoc. 42:135-141.

Berman, D. G., D. E. Johnson, R. W. Phillips, and B. P. Barry. 1980. Physiological and urinary metabolite responses to cold shock and confinement of sheep. J. Anim. Sci. 50:713-722.

Block, E. 1984. Manipulating dietary anions and cations for prepartum dairy cows to reduce incidence of milk fever. J. Dairy Sci. 67:2939-2948.

Bruere, A. N. 1975. Biochemical changes in sheep under stress. Pages 32-37 in Proc. NZ Vet. Assoc. Sheep Soc., Palmerston North, New Zealand.

Cox, V. S. 1981. Pathogenesis of the downer cow syndrome. Pages 5-13 in Proc. Br. Cattle Vet. Assoc., Cheshire, UK.

Damgaard, J. P. 1975. Observations on the relationship between milk fever and sun-spot activity. Dansk Veterinaertidsskrift 58:645651.

Daniel, R. C. W., D. R. Kerr, and C. M. Mulei. 1990. Occurrence and effects of subclinical hypocalcaemia in dairy cows. Proc. N.Z. Soc. Anim. Prod. 50:261-263.

Davies, D. T., C. Holt, and W. W. Christie. 1983. The composition of milk. Pages 71-117 in Biochemistry of Lactation. T. P. Mepham, ed. Elsevier, New York, NY.

Goff, J. P., and R. L. Horst. 1997. Physiological changes at parturition and their relationship to metabolic disorders. J. Dairy Sci. 80:1260-1268.

Goff, J. P., T. A. Rheinhardt, D. C. Beitz, and R. L. Horst. 1995. Breed affects tissue vitamin $\mathrm{D}$ receptor concentration in periparturient cows: A milk fever risk factor? J. Dairy Sci. 78(Suppl. 1):184. (Abstr.)

Heringstad, B., Y. M. Chang, D. Gianola, and G. Klemetsdal. 2005. Genetic analysis of clinical mastitis, milk fever, ketosis, and retained placenta in three lactations of Norwegian red cows. J. Dairy Sci. 88:3273-3281.

Hibbs, J. W., and W. D. Pounden. 1951. The relation of atmospheric pressure to the occurrence of milk fever. J. Am. Vet. Med. Assoc. 118:383-384.

Horst, R. L., J. P. Goff, T. A. Rheinhardt, and D. R. Buxton. 1997. Strategies for preventing milk fever in dairy cattle. J. Dairy Sci. 80:1269-1280.
Houe, H., S. Ostergaard, T. Thilsing-Hansen, R. J. Jorgensen, T. Larsen, J. T. Sorensen, J. F. Agger, and J. Y. Blom. 2001. Milk fever and subclinical hypocalcemia - An evaluation of parameters on incidence risk, diagnosis, risk factors and biological effects as inputs for a decision support system for disease control. Acta Vet. Scand. 42:1-29.

Lean, I. J., P. J. DeGaris, D. M. McNeil, and E. Block. 2006. Hypocalcemia in dairy cows: Meta-analysis and dietary cation anion difference theory revisited. J. Dairy Sci. 89:669-684.

Lindsay, D. B., and D. W. Pethick. 1983. Adaptation of metabolism to various conditions: Metabolic Disorders. Pages 431-480 in Dynamic Biochemistry of Animal Production. A. Neimann-Sorensen and D. E. Tribe, ed. World Animal Science, Series A, Basic Information. Elsevier, New York, NY.

Macdonald, K. A., and J. W. Penno. 1998. Management decision rules to optimise milksolids production on dairy farms. Proc. N.Z. Soc. Anim. Prod. 58:132-135.

Macdonald, K. A., and J. R. Roche. 2004. Condition scoring made easy. Condition scoring dairy herds. 1st ed. Dexcel Ltd., Hamilton, New Zealand.

McCoy, M. A. 1999. Hypomagnesaemia in ruminants: Incidence, clinical biochemistry and control. $\mathrm{PhD}$ Thesis, Queens University, Belfast, UK.

Mishra, M. 1977. Influences of ambient temperature on serum calcium concentration in Holstein steers. Indian J. Dairy Sci. 30:66-67.

Philander, S. G. 1998. Is the temperature rising? The uncertain science of global warming. Princeton University Press, Princeton, NJ.

Reid, R. L. 1962. Studies on the carbohydrate metabolism of sheep. $\mathrm{XV}$. The adrenal response to the climatic stresses of cold, wind and rain. Aust. J. Agric. Res. 13:296-306.

Roche, J. R. 2003a. The incidence and control of hypocalcaemia in pasture-based systems. Acta Vet. Scand. Suppl. 97:141-144.

Roche, J. R. 2003b. Hypocalcaemia and DCAD for the pasture-based transition cow. Acta Vet. Scand. Suppl. 97:65-74.

Roche, J. R., P. G. Dillon, C. R. Stockdale, L. H. Baumgard, and M. J. VanBaale. 2004. Relationships among international body condition scoring systems. J. Dairy Sci. 87:3076-3079.

Roche, J. R., E. S. Kolver, and J. K. Kay. 2005. Influence of precalving feed allowance on periparturient metabolic and hormonal responses and milk production in grazing dairy cows. J. Dairy Sci. 88:677-689.

Sansom, B. F., and R. Manston. 1983. Magnesium and milk fever. Vet. Rec. 112:447-449.

SAS Institute. 2005. SAS User's Guide Version 8.2. SAS Inst., Inc., Cary, NC.

Schnier, C., S. Hielm, and H. S. Saloniemi. 2002. Comparison of the incidence of disease in dairy cows kept in cold and warm loose housing systems. Prev. Vet. Med. 53:247-261.

Schultz, L. H. 1971. Milk fever and ketosis. Pages 321-340 in Digestive Physiology and the Nutrition of Ruminants. Vol. 2. 2nd ed. D. C. Church, ed. Oliver and Boyd Books, Corvallis, OR.

Shiga, A., K. Abe, S. Hamamoto, M. Keino, K. Tsukamoto, and O. Fujio. 1985. Effects of age, milking and season on magnesium, calcium and inorganic phosphorus metabolisms in cows. Jpn. J. Vet. Sci. 47:275-283.

Simensen, E. 1974. Relationship between weather and incidence of parturient paresis and mastitis in dairy cows. Nord. Vet. Med. 26:382-386.

Stockdale, C. R. 2001. Body condition at calving and the performance of dairy cows in early lactation under Australian conditions: A review. Aust. J. Exp. Agric. 41:823-829. 